\title{
Articles
}

\author{
BELÉN LEÓN-RÍO ${ }^{1}$
}

\section{Arte y mito: el poder femenino-masculino de la diosa egipcia y su relación con la doble sexualidad psíquica del ser humano}

\author{
Art and Myth: The Female-Male Power of the Egyptian \\ Goddess and its Relation to the Double Psychic Sexuality \\ of the Human Being
}

\begin{abstract}
RESUMEN
La mitología egipcia refleja un complejo de oposiciones que se relaciona con el carácter bisexual del ser humano a través del poder femenino-masculino de las diosas de la antigüedad, traduciéndose en símbolos universales como la unión de los contrarios o el ser andrógino, símbolos vivos animados por su significado, donde la unión de lo masculino y lo femenino integran nuestra esencia más profunda.

Veremos qué significado tienen estos símbolos que aparecen en todas las tradiciones sagradas, en una búsqueda simbólica tanto interior como exterior y como elevarían nuestros patrones de pensamiento a un nivel arquetípico propiciando la penetración de la fuerza de la diosa en nuestra consciencia, intentando conocer a través de estos procesos las relaciones psicológicas que influyen en el ser humano, siendo su verdadero propósito el descubrimiento de una verdad más profunda, liberándonos de las limitaciones prácticas inmediatas y percibiendo lo mistérico a través de la sublimación del sexo.
\end{abstract}

Palabras clave: bisexualidad, andrógino, diosa, arquetipo, inconsciente.

\section{Abstract}

Egyptian mythology reflects a complex of oppositions that relates to the bisexual character of the human being through the feminine-masculine power of the goddesses of antiquity, translating into universal symbols such as the union of opposites or the androgynous being, animated live symbols by its meaning, where the union of the masculine and the feminine integrate our deepest essence.

We will see what meaning these symbols have that appear in all sacred traditions, in a symbolic search both inside and outside and how they would raise our thought patterns to an archetypal level, propitiating the penetration of the goddess's strength into our consciousness, trying to know through from these processes the psychological relationships that influence the human being, its true purpose being the discovery of a deeper truth, freeing us from the immediate practical limitations and perceiving the mystical through the sublimation of sex.

Keywords: bisexuality, androgynous, goddess, archetype, unconscious. 


\section{SUMARIO}

1. La representación de los contrarios en la mitología egipcia y su relación con los sexos. 2. El ánima como arquetipo de totalidad en la figura de la diosa egipcia. 3. Los mitos egipcios: la unión de los contrarios como medio de superación de la dualidad. Referencias bibliográficas.

\section{La representación de los contrarios en la mitología egipcia y su relación con los sexos}

J. L. Henderson afirma como el rito de la iniciación pondría al hombre en relación con la mujer y viceversa, enmendando una especie de oposición originaria macho-hembra, que es difícil captar por la sociedad actual y que para llegar a comprenderse tiene que darse una crisis especial del individuo:

El conocimiento del hombre (Logos) encuentra entonces la relación con las mujeres (Eros) y su unión se representa como ese ritual simbólico de un matrimonio sagrado que ha estado en el fondo de la iniciación desde sus orígenes en los misterios religiosos de la antigüedad. (Henderson, 1997: 131)

En la mitología egipcia Atón-Ra planea en su corazón la multiplicidad de la creación, haciendo «la primera división entre lo masculino y lo femenino al poner su semen en la boca y escupir a Shu, dios del aire, y a Tefnut, diosa de la humanidad» (Willis, 1993: 40). Shu representa el espacio, ya que sujetaría el cielo y lo separa de la tierra, teniendo como opuesto femenino a Tefnut que simboliza la humedad y según otros autores el fuego, estos gemelos son imagen de la creación. En el «papiro mágico» del Ultimo Reino egipcio fechado alrededor del 300 a. C. titulado Libro del conocimiento de los modos de la existencia de Ra y de victoria sobre la serpiente Apofis, dice como el demiurgo llora sobre estos gemelos creando así a la humanidad: «Shu y Tefnut trajeron mi ojo detrás de ellos después de que recompusiera mis miembros. Lloré sobre ellos y así nació la humanidad.»² (Lamy, 1993, p. 15) Este mito al igual que otros de la antigüedad tiene que ver con esta oposición o par unido donde aparece el cielo y la tierra, manifestándose a través de estas imágenes el carácter bisexual del ser humano. Este hecho se traduce en nuestro pensamiento, donde habría una presencia simbólica «del baile constante entre lo masculino y lo femenino, en una representación avanzada de los hemisferios que alternan y complementan funciones en el complejo juego cerebral del pensamiento» (Pérez de Carrera, 2004: 140). K. Korotkov apunta como el hemisferio derecho del cerebro es femenino mientras el izquierdo es masculino, el lado derecho sería el responsable de las emociones, la sensación de ansiedad y la intuición, mientras que el lado izquierdo lo sería de la lógica, el habla, la planificación y el optimismo, «todo lo mejor del ser humano (la delicadeza, la ternura y la sinceridad) viene del lado derecho del cerebro, y todo racional, providente y estricto, del izquierdo. Ambos hemisferios interactúan intercambiando información» (Korotkov, 2015: 50). 
C. G. Jung basándose en material folklórico, histórico y mitológico pudo comprobar la uniformidad espaciotemporal del acontecer psíquico, siendo el arte un medio que nos permite expresar el inconsciente por medio de oposiciones que mostrarían el conflicto interno y externo que padece el ser humano. El poeta André Breton manifiesta este hecho en su novela Arcane 17 de 1944 cuando escribía: «depende del artista hacer visible todo aquello que forma parte del sistema femenino del mundo, frente al sistema masculino». ${ }^{3}$ El movimiento surrealista consideraba a la mujer como «la heroína mitológica que podía redimir al hombre» (Mahon, 2009: 18), para los surrealistas la mujer era como una «encarnación de Eros; su Alteridad podía enfrentarse al mundo «masculino» del yo, e iniciar el proceso de la conciencia política, subjetiva, y también colectiva» (Mahon, 2009: 18). La armonización del ser humano consistía para los hombres surrealistas en el rescate del poder femenino, concentrando sus obras en el cuerpo de la mujer como celebración del «poder erótico del cuerpo femenino y el ominoso poder de lo femenino que hay en todos nosotros» (Mahon, 2009: 19).

C. G. Jung afirma como el antiguo Eros tendría una divinidad que transcendería los límites de lo humano, un cosmogonos, un creador Padre-Madre de todo conocimiento, siendo el prototipo de la misma divinidad: «Lo que siempre podría ser la interpretación conocida de la frase «Dios es amor»; su contexto confirma la divinidad como «complexio oppositorum».» (Jung, 1996: 357) El alma sería una combinación de los principios macho y hembra, en el Zohar los elementos masculinos y femeninos del alma provendrían de las esferas cósmicas: «La distinción de macho y hembra es un signo de separación (aguas superiores y aguas inferiores; cielo y tierra). En el primer relato de la creación, el hombre es andrógino: la separación aún no ha tenido lugar.» (Chevalier y Gheerbrant, 1999: 698) Esto quedaría plasmado en el mito egipcio donde se produce la unión sexual de Shu y Tefnut que engendraron a «Geb, dios de la tierra, y Nut, diosa del cielo, quienes se fundieron en tan estrecho abrazo que no quedó espacio para que existiera nada entre ellos. Geb dejó embarazada a Nut, pero la diosa no pudo dar a luz a sus hijos hasta que Shu, el padre de ambos, los separó» (Willis, 1993: 40).

S. Zuffi señala como el acoplamiento de Geb y Nut está representado en un papiro egipcio conservado en el British Museum, donde vemos esta unión sexual como una representación cosmológica que aparecerá también en las culturas antiguas mediterráneas:

... Shu, el aire, y Tefnut, el principio húmedo. Estos dos, acoplándose, dieron origen a los dos gemelos primordiales, Geb y Nut. El primero masculino, representado como un gigante tendido de espaldas (el miembro viril es la montaña), representa la tierra. La segunda replegada por encima de él es la noche, o mejor, el cielo estrellado, es decir, la Vía Láctea, que se acopla con él. (Zuffi, 2001: 13)

La diosa Nut engendró dos pares de gemelos, Osiris e Isis y Set y Neftis: «Osiris e Isis se enamoraron en el vientre materno, pero Neftis odiaba a su hermano Set. Por ser el hijo mayor de Geb y Nut, Osiris estaba destinado a gobernar Egipto» (Willis, 1993: 40). J. Chevalier y A. Cheerbrant señalan como todas las culturas y 
mitologías testimoniarían un interés particular por el fenómeno de los gemelos, que representarían una intervención del más allá y la dualidad de todo ser, de sus tendencias espirituales y materiales, diurnas y nocturnas, siendo el día y la noche, junto con los aspectos celeste y terreno del cosmos y el ser humano:

Cuando simbolizan también las oposiciones internas del hombre y el combate que debe librar para sobrellevarlas, revelan una significación de sacrificio: le necesidad de abnegación, destrucción o sumisión, de abandono de una parte de sí mismo en vistas al triunfo de otra. Y estará naturalmente en la fuerzas espirituales de la evolución progresiva asegurar su supremacía sobre las tendencias involutivas y agresivas. (Chevalier y Gheerbrant, 1999: 526)

Como vemos la mitología egipcia muestra la existencia de una doble sexualidad psíquica que correspondería al hecho biológico que investigó C. G. Jung que prueba como el predominio de genes masculinos (femeninos) decidiría en la determinación del sexo masculino (femenino), de manera que el menor número de genes del sexo contrario parecerían formar un carácter contrasexual que, sin embargo a causa de su supeditación permanece habitualmente inconsciente. Este autor denominará ánima y ánimo a estas personificaciones de una naturaleza femenina en el inconsciente del hombre y de una naturaleza masculina en el inconsciente de la mujer. Estas imágenes al ser inconscientes, se proyectarían siempre de manera inconsciente en la figura amada, siendo por esto una de las razones fundamentales de la atracción sexual y su antagónico:

Todo hombre lleva la imagen de la mujer desde siempre en sí, no la imagen de esta mujer determinada, sino de una mujer indeterminada. Esta imagen es, en el fondo, un patrimonio inconsciente, que proviene de los tiempos primitivos, y grabada en el sistema vivo, constituye un «Tipo» («Arquetipo») de todas las experiencias de la serie de antepasados de naturaleza femenina, un sedimento de todas las impresiones de mujeres, un sistema de adaptación psíquica heredado... Lo mismo vale para la mujer, también ella tiene una imagen innata de hombre. La experiencia enseña que se debería decir para ser más exactos: una imagen de hombres, mientras que entre los hombres se trata más bien de una imagen de la mujer. (Jung, 1996: 409-410)

R. Descharnes y G. Néret consideran como esta noción del «doble» condicionaría la obra de Dalí, comenzando con la muerte «prenatal» de su hermano, continuando con la fusión de Vermeer y la espiral logarítmica que se regenera matemáticamente a partir de sí misma, para llegar finalmente a Gala, que sería su nuevo doble:

Ellos son «Castor y Polux, los divinos gemelos estereoquímicos» que Dalí tomó como ejemplo para convertirse en «gemelo» de su esposa y tener así, «por el mismo precio, dos memorias en lugar de una y posiblemente tres, lo que debe hacer más densa la persistencia de la inmortalidad de la memoria». ${ }^{4}$

4 Autor citado por R. Descharnes, G. Néret, Salvador Dalí 1904-1989, Taschen, Boonn, 2006, p.168. 
Dalí consideraba al ánima como a un ser personal en la figura de Gala de la que dependería forzosamente no sólo en su vida sino también en su obra escribiendo:

Yo no existiría más que en un saco lleno de agujeros, blando y borroso, siempre en busca de una muleta. Ciñéndome a Gala he encontrado una columna vertebral $y$, haciendo el amor con ella, he rellenado mi piel. Hasta este momento mi esperma se perdía por la masturbación como arrojado a la nada, con Gala lo he recuperado y me ha vivificado. Primero creí que ella iba a devorarme; pero por el contrario, me ha enseñado a comer lo real. Firmando mis cuadros con Gala-Dalí no hago más que dar nombre a una verdad existencial, porque no existiría sin mi gemela Gala. ${ }^{5}$

Dalí y Gala encarnaban el mito de los Dióscuros nacidos de uno de los dos huevos divinos de Leda, este tipo de figuras semejantes a dioses serían representante simbólico de la totalidad de la psique del artista, ya que encarnarían una mayor identidad que proporcionaría la fuerza de la cual carece el ego personal, cuya función sería desarrollar la consciencia del ego individual, para que reconozca su propia fuerza y debilidad para enfrentarse a las arduas tareas de la vida: « ... la imagen del héroe evoluciona de una manera que refleja cada etapa de la evolución de la personalidad humana» (Henderson, 1997: 110).

\section{El ánima como arquetipo de totalidad en la figura de la diosa egipcia}

Los arquetipos señalarían vías determinadas a toda actividad de la fantasía, que producirían paralelos mitológicos y que C. G. Jung ha encontrado no sólo en las creaciones artísticas y en los sueños infantiles, sino también en los delirios de la esquizofrenia y en los sueños de las personas normales. Estos arquetipos serían formas típicas de conducta que cuando llegan a ser conscientes, se manifiestan como representaciones, al igual que todo lo que llegaría a ser contenido de consciencia. Estos contenidos del inconsciente colectivo, pueden influir sobre el yo de manera perturbadora, como ocurre con el ánima y el ánimo. El ánima como vimos sería una personificación de todas las tendencias psicológicas femeninas en la psique del hombre, teniendo un carácter eminentemente histórico como personificación del inconsciente, pudiéndose presentar como fundamento de figuras divinas y semidivinas, como ocurre con la antiquísima Isis, la divinidad egipcia de la fertilidad cuyo culto se extendió entre los soldados griegos y romanos en todo el mundo greco-romano, a la que identificaban con Perséfone y Deméter. Isis era considerada en las religiones de misterio de los primeros siglos como "principio femenino, fuente mágica de toda fecundidad y transformación» (Chevalier y Gheerbrant, 1999: 595). Para todos los círculos esotéricos será la iniciadora «la que detenta el secreto de la vida, la muerte y la resurrección» (Chevalier y Gheerbrant, 1999: 595). Isis fue capaz de arrebatar el nombre secreto del dios supremo Ra haciendo que su poder divino se expandiera por el universo: 
Yo soy la madre y la naturaleza entera, señora de todos los elementos, origen y principio de los siglos, divinidad suprema, reina de los mares, primera entre los habitantes del cielo, tipo único de los dioses y las diosas. Las cumbres luminosas del cielo, los soplos salvadores del mar, los silencios desolados de los infiernos... yo soy quien gobierna todo a merced de mi voluntad. ${ }^{6}$

Isis era en Egipto la diosa de los cereales y la fertilidad siendo también adorada como «Madre de las Madres» (Dunn, 1990: 155). Purusha y Prakriti forman al igual que Isis y Osiris la eterna dicotomía creadora en la mitolgía hindú. Purusha es el hombre antropocósmico, paradigmático o semilla que proyecta a Prakriti, el eterno encanto femenino, con el fin de que su matriz pueda concebir su propia encarnación en el mundo de la forma. Prakriti es el poder femenino de la creación y «la manifestación de la Madre Universal, la quintaesencia del universo natural» (Lawlor, 1993: 103). C. G. Jung considera que la función natural de estas personificaciones (ánima y ánimo) sería crear un vínculo entre la consciencia individual y el inconsciente colectivo. En el arte este hecho se suele producir cuando el creador plástico representa en su obra, una esfera entre la consciencia del yo y el objeto del mundo externo, como expresa el artista Austin Spare en su obra titulada Isis sin velo de 1954, donde aparece la diosa Isis «penetrando en el santuario más secreto de los misterios egipcios» (King, 1993: 92). Según C. G. Jung lo inconsciente del hombre tendría un signo femenino, que ocultaría en su lado femenino, que el hombre no percibiría como tal, sino que lo encontraría de forma más natural en la mujer que lo fascina, por eso este autor considera que el alma del hombre sería de sexo femenino llamándola ánima:

En cuanto se produce entre el hombre y la mujer una identidad inconsciente de cualquier género, el adquiere los rasgos del animus de ella, y ella los del anima de él. Si bien ni el animus ni el anima llegan a constelizarse sin la intervención de una correspondiente personalidad, esto no significa que la situación así originada sea otra que una relación e intriga personales. (Jung, 1993b, p. 127)

C. G. Jung destaca como estos arcaísmos no son adquisiciones personales, sino cuando menos residuos de una psique colectiva anterior. Estas asociaciones e imágenes serían parte integrante del inconsciente, no habiendo «remanentes» sin vida o sin significado, estos seguirían funcionando, siendo especialmente valiosos a causa de su naturaleza histórica. Ejemplo de ello es la figura de Cleopatra que se ha convertido en una gran leyenda que ha perdurado a lo largo de la historia. Los egipcios siempre asociaron su personalidad «con la sabiduría y la atracción sexual, y la atribuyeron una colección de cosméticos y de remedios medicinales» (Manley, 2004: 151), su suicidio «es una de las obras magnas de la historia, inmortalizado en el drama de Shakespeare, numerosas películas e incontables cuadros» (Manley, 2004: 150). Pintores románticos como Jean-François Gigoux o Jean André Rixens se inspiraron también en su figura. Los artistas del Manierismo y el Barroco como 
Rosso Fiorentino, Guido Reni, Johan Liss o Guido Cagnacci la representan «sentada en un sillón, con el áspid enroscado en torno al antebrazo y la mirada casi siempre elevada al cielo, en una actitud sublime» (Solana, 2009: 64). Según G. Solana el «suicidio de Cleopatra se presenta como un acto casi viril, más allá de la debilidad femenina...» (Solana, 2009: 66), convirtiéndose por eso en mármol en Antonio y Cleopatra de Shakespeare: «En la escena culminante de la tragedia, cuando le traen el áspid, la reina declara solemnemente que ha dejado atrás la proverbial volubilidad femenina para volverse "constante como el mármol".» (Solana, 2009: 65).

C. G. Jung había observado en algunos artistas, que el yo no estaría localizado en la persona como relación con el mundo real, sino que el yo sé localizaría más bien en el ánima como relación con el inconsciente colectivo, de forma que individuo y persona serían juntamente inconscientes: «el inconsciente colectivo forma entonces una parte de la conciencia, y gran parte del mundo real se constituye en contenido inconsciente. Estos sujetos experimentan ante la realidad el mismo temor a lo demoniaco que el hombre común ante el inconsciente» (Jung, 1993a: 215).

C. Downing afirma como no podemos sólo alimentarnos de imágenes masculinas divinas, sino que también tendríamos «hambre de imágenes que reconozcan la sacralidad de lo Femenino y la complejidad, riqueza y poder nutritivo de la energía femenina... ${ }^{7}$ Como vemos en el caso de Isis, diosa de la Luna que pertenecería a un orden matriarcal, ya que esta diosa Madre-Luna sería «una diosa del amor sexual pero no de matrimonio. No hay dios masculino que como marido gobierne su conducta ni determine sus cualidades. En cambio, es madre de un hijo al que controla» (Harding, 2010: 245). Su leyenda relata como la diosa Isis tras recoger los pedazos del cuerpo de Osiris descuartizado por su hermano Set, cópula con su pareja Osiris descendiendo en forma de pequeña ave para quedar embarazada: «Como resultado dará a luz al hijo de Osiris, Horus, quien completará la regeneración de su padre.» (Manley, 2004: 215) Isis al dar a luz a su hijo, lo cría en la localidad de Chernis estando «protegida por varias deidades, como Selker, la diosa-escorpión y esperó hasta que Horus tuvo edad para vengar a su padre» (Willis, 1993: 43). Estas diosas «grandes y poderosas» no reflejarían las características de sus compañeros masculinos: «Sus historias son independientes, y sus funciones, sus insignias y sus ritos pertenecen sólo así mismas, pues representan la esencia de lo femenino en su más agudo contraste con la esencia de la masculinidad.» (Harding, 2010: 245)

La virginidad de Isis tendría que ver con «el símbolo de su propia individualidad de carácter, de ser "una misma"»(Dunn, 1990: 159). La selección que hace Isis al elegir a Osiris como padre de su hijo, es una cuestión más de compañerismo que de dependencia: «Al igual que la reina Isis, siempre será una mujer y una amante para él, manteniendo los roles de madre y de compañera de un hombre bien definidos.» (Dunn, 1990: 159) La diosa Isis se la veneraba como virgen-madre y se la representa sedente y amamantando a Horus, imagen heredada más tarde por el cristianismo con la Virgen María y el niño. Isis aparece como una diosa cósmica que incluye en su figura las fuerzas de la existencia como la vida, la muerte y el renacimiento. Según

7 Autora citada por C. Zweig, Espejos del yo, Imágenes arquetípicas que dan forma a nuestras vidas, Kairós, Barcelona, 2010, p. 256. 
J. Campbell la madre cósmica se fue devaluando progresivamente cuando antes estaba sobre el padre, produciendo resultados filosóficos y efectos psicológicos, que produjeron una «maduración del Estado dinástico y el patriarcado» (Campbell, 1991: 137), culminando en el suroeste de Asia, donde desaparece la diosa madre de la mitología del Antiguo Testamento. M. E. Harding considera que el principio femenino no se ha sido reconocido y apreciado de verdad en nuestra cultura:

Y aún hoy, cuando las manifestaciones externas de esta unilateralidad han sufrido cambios considerables, los efectos psicológicos perduran y tanto hombres como mujeres tienen una psique mutilada en vez de plena. Tal situación está representada por la diosa que es la contrapartida del dios masculino y nada más. (Harding, 2010: 245).

En la actualidad muchas mujeres están intentando despertar «lo femenino divino» (Zweig, 2010: 254), explorando el ámbito mitológico y el despertar de una espiritualidad femenina, emergiendo así «... la Diosa, tanto si la concebimos como una figura única y transcendente o como diosas plurales que representan las diversas energías de la vida» (Zweig, 2010: 255). Para C. Zweig «el arquetipo emergente de lo femenino consciente puede añadirse al rico legado de imágenes arquetípicas de otras culturas» (Zweig, 2010: 256).

A través de la mitología podemos aprender «aspectos fundamentales de la psique femenina, de investigar las relaciones entre el cuerpo femenino y sus funciones, así como la mitología de la Diosa y sus símbolos» (Dunn, 1990: 23). Las mujeres artistas se acercarían de manera inconsciente a esta simbología que subyacería en nuestro interior, viendo más allá de la superficie de las cosas mediante el subjetivismo, así Betsy Damon realiza en 1977 una performance titulada 7.000 Year-old Wooman, donde se identifica con una mujer de 7.000 años, diciendo que se sentía en su performance como «una antigua diosa de la fertilidad $»^{8}$ También Carolee Schneemann reivindica el poder femeninomasculino de la diosa con su performance Interior Scroll de 1975, donde representa el conducto vaginal como una forma escultórica:

Consideré la vagina de formas distintas: física y conceptualmente, como una forma escultórica, un referente arquitectónico, el origen del conocimiento sagrado como éxtasis, nacimiento, transformación [...] Este origen del "conocimiento interno» se simbolizaría como el indicador principal que une el espíritu y la carne en la veneración de la Diosa. ${ }^{9}$

Las mujeres artistas demandarían una concepción más femenina-maternal de nuestra sociedad, poniendo de relieve a través de su obra nuestro desarrollo psicológico, que tendría que ver con la evolución de nuestra consciencia

8 Autora citada por H. Reckitt y P. Phelan, Arte y feminismo, Phaidon Press Limited, Barcelona, 2005, p. 80.

9 Autora citada por T. Warr, y A. Jones, El cuerpo del artista, Phaidon, Londres, 2006, p. 144. 
valiéndose de símbolos y arquetipos integradores de contenidos inconscientes, que totalizan al ser humano produciendo consecuencias muy importantes, como la transformación de nuestra visión del mundo y de la sociedad, donde lo femenino estaría cobrando un renovado poder frente al patriarcado. La mitología de la Diosa y sus arquetipos tendrían un efecto en nuestra esencia femenina, estos mitos nos describirían «los momentos más íntimos de la vida de una mujer, como enamorarse o dar a luz» (Dunn, 1990: 12). La mitología se convierte así en materia que se transforma evocándonos sentimientos que tienen que ver con nuestra existencia:

El misterio de la sexualidad femenina, de la partenogénesis, de la asociación del ciclo femenino con el ritmo de la luna, de la tierra entendida como vientre, de la muerte de la semilla para la creación, son motivos fundamentales de la mitología de la Diosa Madre. (Dunn, 1990: 28)

En la mitología anterior a la Edad del Bronce que tuvo gran importancia en la India, China, Sumer, Egipto y Creta «la mujer desempeña funciones rituales y como diosa universal personifica el poder de maya dentro del campo que contiene todas las formas y pensamientos (incluso los dioses), se puede adorar al poder femenino como superior al masculino, puesto que es anterior a éste» (Campbell, 1992: 693). En el neolítico la mujer estaba por encima del hombre «la madre cósmica sobre el padre» (Campbell, 1991: 137), esto dio un vuelco más tarde «con la devaluación progresiva de la diosa madre a favor del padre que acompañó» (Campbell, 1991: 137). En Egipto se mantuvo este culto matriarcal a través de la diosa-vaca Hathor que al igual que la diosa Tauret protegía a las mujeres y a los niños al dar a luz. Ella criará en Chemis a Horus adoptando la forma de vaca y en el inframundo daba de beber y comer a las almas. La diosa Kudshu que podía presentarse como Hathor, era consorte de «Min, dios egipcio de la fertilidad» (Campbell, 1991: 51). Según J. Cambell la diosa Hathor se identificaba con el culto a la diosa Vaca cósmica neolítica:

La verdad, maat, el orden correcto, está personificado mitológicamente en la diosa-vaca Hathor. Ella es el principio siempre presente en el que se apoya el mundo: tanto su marco como su fuerza maternal, dando vida al dios realizado y al mismo tiempo fructificada en este acto. (Campbell, 1991: 73)

La diosa Nut es descrita en los Textos de las Piramides como la gran protectora «la del pelo largo, la de los pechos colgantes» (Campbell, 1991: p. 136). Esta diosa aparece representada en la paleta de Narmer como la diosa-vaca Hator que más tarde será Nut la diosa antropomórfica cuyo cuerpo forma la bóveda del mundo:

Hathor se alzaba sobre la tierra de forma que sus cuatro patas eran los pilares de los cuatro puntos cardinales. Su vientre era el firmamento. El sol, el halcón solar dorado, el dios Horus, que volaba de este al oeste, entraba en su boca cada tarde para nacer de nuevo al alba. (Campbell, 1991: 70-71) 


\section{Los mitos egipcios: la unión de los contrarios como medio de superación de la dualidad}

Los teúrgos, protomagos neoplatónicos tuvieron un gran aprecio por el saber del antiguo Egipto ya que les proporcionaba una comprensión intuitiva de las realidades cósmicas, así los textos que componen la literatura hermética estaban redactados al igual que gran parte de las escrituras tántricas, en forma de diálogos didácticos entre dioses y diosas: «Entre las divinidades que aparecen en ellos figuran el propio Hermes, Isis diosa de los misterios, Tat, otra manifestación de Thonth, e Imhotep, un científico divinizado» (King, 1993: 41). E. Butelman dice como el dualismo sexual común a todos los hermetistas, sería de particular importancia para la interpretación psicológica de la teoría del dualismo sexual, donde aparece Dios antes de la creación como hermafrodita que se dividiría posteriormente en dos seres de sexo opuesto: «Del posterior ayuntamiento de ellos proviene el mundo, obedeciendo todas las afinidades y antagonismos que cabe verificar en ése a la contraposición de dos principios complementarios: uno activo, masculino, y otro pasivo, femenino.» ${ }^{10}$ La Diosa se adoraba ya en la antigüedad por su doble poder creativo y destructivo encarnando en ella misma las fuerzas cósmicas: «Era símbolo de todos los contrarios de la vida, encerrando en su figura el respeto que los antiguos sentían por la vida, donde los buenos y malos momentos, divinos o demoniacos, se combinan en un todo.» (Dunn, 1990: 80) El símbolo hermafrodítico tiene una naturaleza opuesta, siendo resultado de hechos psicológicos que se fundamentarían en nuestro pasado evolutivo pero también nuestro futuro, como vemos en la mitología egipcia donde aparecen símbolos e imágenes que desarrollan ciertos temas inconscientes o arquetipos relacionados con la bisexualidad y la unión de los contrarios, representados en muchos casos en forma de polaridades metafóricas o explícitamente sexuales. Así en la mitología menfita el herrero divino Ptah tiene como equivalente femenino a Sekhmet la leona, llamada la poderosa que representaría según L. Lamy «la acción catalizadora del <fuego estíptico> que concentra y "precipita la energía, dándole forma"» (Lamy, 1993: 46). La leona Sekhmet aparece en el templo de Khonsu de Karnak con el brazo levantado que sujeta el mayal que atrae la energía celeste representándola «con un falo erecto y con el disco solar rodeado por el uraeus en la cabeza» (Lamy, 1993: 46). Esta diosa leona será la encargada de matar a la humanidad rebelde, sacrificándose «delincuentes en su honor» (Lamy, 1993: 50). La diosa Bast se la representaba en forma de gata a partir del II milenio a. C. siendo la «diosa del amor, el sexo y la fertilidad» (Lamy, 1993: 50). También la diosa Tauret era una deidad que podía transformarse en hipopótamo, pudiendo presentarse «como una bestia temible, parte hipopótamo, parte león y parte cocodrilo» (Lamy, 1993: 51). La transformación de la mujer en diferentes animales como vemos en la diosa como musa, estaba relacionada con la secuencia de las estaciones procedente de «la triple Diosa, protectora de las tres Estaciones y de las bestias salvajes» (Dunn, 1990: 221). Esta creación-destrucción

10 E. Butelman prólogo de C. G. Jung, La psicología de la transferencia, Col. Biblioteca Profunda nº, Paidós, Barcelona, 1993, p. 14. 
tendría que ver con símbolos de poder que representarían la ambivalencia de la naturaleza cíclica de la mujer:

Los movimientos del inconsciente que la asedian durante los cambios hormonales en el ciclo mensual se han elevado al plano superior del mito y la fantasía, en el que las Diosas son capaces de crear y destruir mundos y entidades a su antojo. (Dunn, 1990: 84)

En la mitología egipcia las deidades femeninas «inspiran más temor que las deidades masculinas y envían la guerra y la destrucción contra quien las encolerizan» (Willis, 1993: 50). Así entre las diosas extranjeras que los egipcios incorporaron a su panteón a finales del II milenio a. C. destacan diosas guerreras poderosas consortes de los dioses, como Kudshu que era compañera de Min, dios egipcio de la fertilidad, esta deidad se la representa desnuda a lomos de un león, con serpientes y flores de loto. Otra diosa guerrera será Anat, amante y hermana de Baal, dios sirio que en Egipto se identificaba con el dios Set: «En la mitología egipcia, Anat era hija de Ra. Vestía como un guerrero varón, pero era asimismo una diosa vaca.» (Willis, 1993: 51). Astarte era hija del dios del sol o de Ptah, se la representaba a veces en forma de caballo, apareciendo «como una mujer desnuda con armas» (Willis, 1993: 51).

Las diosas egipcias muestran el poder de su lado masculino unido al femenino como ejemplo del equilibrio que opera en nuestro interior, ya que lo masculino también padecería una desarmonía si se produce la pérdida de lo femenino, ante esta situación C. Zweig propone una renovación, esclarecimiento y renacimiento de lo masculino en nosotras: «Con su aparición, tenemos una gran oportunidad para hacer alquimia espiritual, para encontrar el misterio del Otro en el matrimonio sagrado» (Zweig, 2010: 257). La psiquis del individuo no podría elevarse más allá de sí misma, ya que no podría establecer verdades absolutas, esto se debería a su polaridad que condicionaría la relatividad de sus manifestaciones. Así a la tesis le seguiría la antítesis «y entre ambas existe una tercera lisis que antes no se percibía. Con este proceso la psiquis sólo afirma de nuevo su polaridad y no ha conseguido en absoluto transcendencia a sí misma" (Jung, 1996: 355).

La psicología personal del artista, su entorno social y su doble sexualidad psíquica serán de vital importancia para aproximarnos a la obra artística del siglo XX que presentaría a un ser humano con capacidad de metamorfosis. Así en la escultura de Henry Moore titulada Rey y reina de 1952-1953, se produciría una integración de la personalidad del artista, mediante la conciliación de lo inconsciente (principio femenino) representado por la reina, con el espíritu (principio masculino) representado por el rey, esta escultura tendría la misma composición que la escultura de Rahotep y Nofret de la IV Dinastía pertenecientes al reinado de Snofru (2575-551 a. C.). Apareciendo también en el tema fundamental de regeneración y renacimiento de la leyenda mítica de la triada de Osiris hermano y esposo de Isis, de cuya unión nace su hijo Horus. En los templos se representaba este mito donde «todo rey era producto de una unión sexual entre su madre humana, la reina, y un dios; o entre su padre humano, el rey anterior y una diosa» 
(Manley, 2004: 215). En el Midrasch bereshit Raba dice que Dios creó a Adán al mismo tiempo macho y hembra, teniendo idéntico sentido en la Cábala, donde habla de Dios bajo aspecto de rey y de reina. Henry Moore presentaría el núcleo interior de la psique, en una visión de la pareja real que se remontaría a otras parejas mitológicas que emergería de las profundidades de la naturaleza animal y del estrato primitivo del inconsciente, como explica el propio artista:

Tal vez la «pista» del grupo está en la cabeza del Rey, que es una combinación de una corona, una barba y una cara que simbolizan una mezcla de dignidad real primitiva y una calidad animal como la de Pan. El Rey está en una postura más reposada y confiada que la reina, que está más erguida y más conscientemente regia. ${ }^{11}$

Escoto de Erígena refiriéndose a la creación de Adán, dice que la separación de los sexos se integraría en un proceso cósmico donde el origen de esta división de la naturaleza humana se remontaría a Dios, ya que en la medida que el hombre reúne en él lo masculino y lo femenino, esta unión alcanza todos los planos del ser, de manera que llegar a ser uno sería la meta de la vida: «Lo masculino y lo femenino no son sino uno de los aspectos de una multiplicidad de opuestos llamados a interpretarse de nuevo.» (Chevalier y Gheerbrant, 1999: 97) La divinidades egipcias femeninas suelen representar en sus atributos estos dos aspectos integrados como vemos en la Gran Madre o diosa Neith cuyo escudo tiene dos flechas cruzadas, siendo diosa de la caza y la guerra, pero también «una deidad creadora, que surgió del Nun para crear a Dioses y hombres, y al escupir en aquel abismo acuoso, de su saliva nació Apep, la serpiente del caos» (Willis, 1993: 50). Estas deidades mostrarían el inconsciente femenino originando una simbólica que adoptaría una actitud compensatoria respecto a la masculina. C. G. Jung cree que aunque en general el ánimo o el ánima tienen manifestaciones negativas también pueden tener aspectos positivos, ya que a causa de su positivo y numinoso poder de sugestión, representan los fundamentos arquetípicos de las divinidades masculinas y femeninas, su oposición mutua sería la de los sexos:

Por eso constituyen un par de oposiciones supremo, cuyos miembros no están irremediablemente separados por contradicción lógica, sino que, debido a su peculiar atracción recíproca, prometen y también posibilitan su unión. La coniunctio oppositorum ha suscitado las especulaciones de los alquimistas en la forma de las «bodas químicas», así como las de la Cábala en la forma de Tiferet y Malkhût o de Dios y la Shekhina, para no mencionar directamente las Bodas del Cordero. (Jung, 1995: 281)

Willian Blake llamaría a este aspecto femenino emancipación, y al masculino, espectro. Ambos aspectos se combinarían y se redimirían de la emancipación, siendo ésta la meta y fin primordial de nuestra existencia terrenal: «El camino que conduce 
a ello pasa, según Blake, por las alegrías de la sensualidad y por la satisfacción corporal. Este camino se ve obstaculizado por las falsas doctrinas morales y las religiosidad dogmática que son el principal instrumento de la represión sexual.» (Roob, 1997: 460) En la obra de Blake llamada Jerusalen de 1804-1820, vemos la escena de la creación de Eva a partir de la costilla de Adán, justo antes de separarse. A. Roob explica que después de que Adán cayera en el suelo mortal de la materialidad, abandonaría de esta forma la androginidad celestial. Cristo le acompañaría en este descenso creando a Eva para posibilitar la salvación. Boehme lo describe así: «Cristo apartó a Adán, durante el sueño, de su vanidad (...) y le devolvió la imagen angélica creando a Eva de su propia esencia, de su parte femenina. Ella es la matriz de Adán, de naturaleza celestial (Sophia.)» ${ }^{12}$ M. L. von Franz considera la idea del alma divina, también llamada Sabiduría de Dios o el anima mundi, como uno de temas mitológicos más importantes del pensamiento alquímico, que se representaría como una figura femenina que se desprendería de Adán original y caería a la materia, debiendo ser rescatada. Para esta autora este mito significaría la búsqueda «del inconsciente, o de la imagen de la Divinidad femenina, o de la experiencia del hombre divino en la materia» (Franz, 1999: 311-312).

M. L. von Franz concluye que el ánima tendría en la práctica un papel como guía en el interior del individuo, de manera que esta función positiva se produciría "cuando un hombre toma en serio los sentimientos esperanzas y fantasías enviadas por su ánima y cuando los fija de alguna forma» (Franz, 1997: 186). Según esta autora esto se podría hacer mediante el arte, cuando el individuo trabaja en ello de forma paciente y continuada, de esta forma iría surgiend o otro material inconsciente más profundo, como la representación simbólica de la unión de lo femenino y lo masculino en los procesos de la naturaleza y de la vida, expresándolos en la unificación de los contrarios.

E. Pérez de Carrera señala como el carácter bisexual del ser humano es uno de los factores que determinan su comportamiento básico, donde leyenda, deseo y realidad se mezclarían en una búsqueda mistérica simbólica endógena y exógena, que siempre habría sido y sigue siendo una fuente de conflictos, en la que nacerían y crecerían obsesiones, miedos, alteraciones y riesgos que provocarían desconciertos y trastornos que irían degradando los neurotransmisores. Todo esto ha llevado al ser humano a cometer uno de sus mayores errores: «... separar el encuentro interior, bautizándolo como camino espiritual, del exterior al que se dio categoría de superficial, intranscendente y mundano» (Pérez de Carrera, 2004: 141), esto habría provocado de forma creciente «el sentimiento general del sexo ligado al poder» (Pérez de Carrera, 2004: 141). En el plano biológico esta polaridad también estaría presenta en nuestro funcionamiento energético, la descarga de cualquier hormona se puede llegar a percibir, provocando placer o sufrimiento, siendo en algunas peculiaridades de la sexualidad donde se percibiría con más intensidad. Este hecho hizo creer a Freud que la mente del individuo tendría una excesiva y casi exclusiva dependencia de las fantasías sexuales, definiendo «el subconsciente

12 Autor citado por A. Roob, El museo hermético. Alquimia E Mística, Taschen, Madrid, 1997, p. 460. 
en su mayoría como un saco de frustraciones sexuales reprimidas y sometidas a una tapadera de energía que les impide salir» (Pérez de Carrera, 2004: 137). E. Pérez de Carrera señala como esta forma modélica de esquematizar al individuo, habría sido la dominante durante la mayor parte del siglo XX continuando en nuestros días, pero en esta esquematización, no se contemplaría que la obsesión sexual sería un estímulo condicionado por el hecho de que el ser humano todavía estaría en vías de evolución y que aún tendrá que saber percibir lo mistérico a través de la sublimación del sexo, para llegar a metas más altas. Esto ya se habría planteado en la antigüedad no sólo en el quinto Veda, sino también en los ritos órficos y en los estudios pitagóricos secretos:

Es la experimentación del ritmo telúrico, del ritual mecánico del zen, como un canto a la vida para llegar al éxtasis de la muerte en la seguridad de la resurrección. Es por lo tanto un rito arquetípico en sus dos sentidos de memoria de futuro, no exclusivamente ligado a la reproducción, pues es obvio precisar que la disponibilidad sexual humana no depende de ciclos temporales ni de estados de fertilidad, sino de actitudes sensoriales activadas por aspectos fantásticossensitivos y emocionales. (Pérez de Carrera, 2004: 137-138)

Este autor señala como algunos sociólogos creen, que cuando los individuos buscan la aproximación sensosexual, estarían intentando completar y contemplar sus propios arquetipos, que serían deformaciones psíquicas de la mente como consecuencia de nuestra herencia colectiva ancestral, y como la tendencia a creer que la dualidad sería un destino y no una transición, se estaría haciendo presente en el comportamiento de nuestra energía, de nuestro pensamiento convencional e incluso «del aparente desorden de la materia, pero sólo es una vibración plana al encuentro de lo trinitario, que cierra el principio de lo manifestado y dimensiona el amor más allá del deseo y la necesidad» (Pérez de Carrera, 2004: 142). Pues como reza el conjuro de los Textos de las pirámides:

Uní mis miembros, que surgieron de mí. Tras producirme excitación con el puño, mi deseo se realizó con mi mano. La simiente cayó de mi boca. Esputé a Shu, expectoré a Shu, expectoré a Tefnut. Mientras que antes era uno, ahora soy tres. ${ }^{13}$

M. Woodman afirma como el poder que está actualmente ejerciendo el patriarcado tiene que ser transformado. «Ha de haber un contrapeso a todo este frenesí, aniquilación, competición y materialismo.» ${ }^{14}$ En el arte y la mitología la androginia es representada como un estado inicial que debe ser reconquistado y donde llegar a ser uno sería la meta de nuestra vida. El ser humano puede sentir, percibir y captar su propia verdad y su naturaleza, a través de estos símbolos que revelarían una realidad interior-exterior, que tiene que ver con nuestra esencia más profunda conduciéndonos a una iniciación interior.

13 Autor citado por p. L. Lamy, Misterios egipcios, Debate, 1993, p. 15.

14 Autora citada por C. Zweig, Espejos del yo, Imágenes arquetípicas que dan forma a nuestras vidas, Kairós, Barcelona, 2010, p. 256. 


\section{Conclusiones}

En el arte y la mitología sagrada de Egipto al igual que ocurre en otras culturas antiguas aparecen arquetipos duales y contrapuestos que representan un estado inicial que debe ser reconquistado por la humanidad y que tendría que ver con la evolución de nuestra consciencia. Esta mitología constituiría una herencia colectiva anterior donde aparecen asociaciones e imágenes hermafroditas de naturaleza opuesta relacionadas con la bisexualidad y la unión de los contrarios que siguen en funcionamiento, siendo especialmente valiosos a causa de su naturaleza histórica y por su poder de transformación a través de lo femenino y el matriarcado. Así las diosas egipcias muestran el poder de su lado masculino unido al femenino mediante símbolos de transformación, creación y destrucción que representan la ambivalencia de la naturaleza cíclica de la mujer y del equilibrio que opera en nuestro interior como vemos en la mitología menfita donde Ptah tiene como equivalente femenino a Sekhmet la leona, mientras que otras diosas presentan la capacidad de transformarse en distintos animales como Bast y la diosa Tauret entre otras. Estas deidades encarnarían las fuerzas cósmicas de la naturaleza como ocurre con la diosa Isis cuyo poder se extiende por el universo o la diosa antropomórfica Nut cuyo cuerpo forma la bóveda del mundo. Entre las diosas extranjeras que los egipcios incorporaron a su panteón a finales del II milenio a. C. destacan diosas guerreras poderosas consortes de los dioses como Kudshu, Anat o Astarte siendo parejas mitológicas representativas del núcleo interior de nuestra psique.

Estos símbolos del arte, la mitología y los ritos de iniciación encarnan verdades fundamentales de nuestra naturaleza que nos muestran como el ser humano poseería una doble sexualidad psíquica que se traduciría en su pensamiento donde habría una presencia simbólica entre lo masculino y lo femenino, como vemos en el mito de creación donde Atón-Ra divide lo masculino y lo femenino escupiendo de su boca a el dios del aire Shu y a la diosa de la humanidad, Tefnut. Estas personificaciones de nuestro inconsciente son denominadas por C. G. Jung como ánima y ánimo, relacionándose con la atracción sexual y su antagónico de manera que el alma del hombre inconscientemente ocultaría su lado femenino o ánima que se proyectaría en la figura amada, encontrándola de forma natural en la mujer que lo fascina.

El ánima tendría como misión guiar al hombre en su interior pudiendo aflorar material inconsciente, mediante la representación simbólica que se generaría en el proceso artístico, mediante esta función, tanto el artista como el espectador pueden percibir el poder sagrado de lo femenino. Mientras que las mujeres artistas a través del poder de la diosa, demandarían una concepción más femenina-maternal de nuestra sociedad, mediante símbolos y arquetipos integradores de contenidos inconscientes que totalizan al ser humano, produciendo consecuencias muy importantes como la transformación de nuestra visión del mundo y de la sociedad, donde lo femenino estaría cobrando un renovado poder frente al patriarcado. 


\section{Referencias bibliográficas}

CAmbell, Joseph. (1992). Las máscaras de Dios: Mitología creativa, Madrid: Alianza Editorial.

- (1991). Las máscaras de Dios: Mitología oriental, Madrid: Alianza Editorial.

Chevalier, Jean. GheErbrant, Alain. (1999). Diccionario de los símbolos. Barcelona: Heder.

DeSCHARNES, Robert y NéRET, Gilles. (2006). Salvador Dalí 1904-1989, Boonn: Taschen.

Dunn Mascetri, Manuela, (1990). Diosas. La canción de Eva. Barcelona: Ediciones Robinbook.

Franz, Marie-Louise von. (1999). Alquimia. Introducción al simbolismo. Barcelona: Océano. JafFé, Aniela, Jung, Carl Gustav. Franz, Marie-Louise von. Henderson, Joseph. Jacobi, Jolande. (1997) El hombre y sus símbolos, Barcelona: Col. Biblioteca Universal n ${ }^{\circ} 3$, Caralt.

Jung, Carl Gustav. (1993a). Las relaciones entre el yo y el inconsciente. Barcelona: Col. Biblioteca de Psicología Profunda n ${ }^{\circ} 114$, Paidós.

- (1993b). La psicología de la transferencia, Barcelona: Col. Biblioteca Profunda n ${ }^{\circ} 6$, Paidós.

- (1995). AION. Contribución a los simbolismos del sí-mismo. Barcelona: Col. Biblioteca de Psicología Profunda n ${ }^{\circ} 113$, Paidós.

- (1996). Recuerdos, sueños, pensamientos. Barcelona: Col. Biblioteca Breve, Seix Barral. KING, Francis. (1993). Magía, Madrid: Debate.

Kовоткоv, Konstantin. (2015). La energía de la consciencia, Barcelona: Ediciones Obelisco. Lamy, Lucie. (1993). Misterios egipcios, Madrid: Debate.

MaHon, Alyce. (2009). Surrealismo, Eros y política, 1938-1968, Madrid: Alianza Editorial. MANLEY, Bill. (2004). Los setenta grandes misterios del antiguo Egipto, Barcelona: Blume. Mitchinson, David. (1981). Henry Moore. Escultura, Barcelona: Polígrafa, Barcelona. Pérez de CARrera, Eduardo. (2004). 49 Respuestas a la aventura del pensamiento, tomo I. Madrid: Fundación Argos.

Reckitt Helena y Phelan, Peggy. (2005). Arte y feminismo, Barcelona: Phaidon Press Limited.

Rooв, Alexander. (1997). El museo hermético. Alquimia \& Mística, Madrid: Taschen. SolanA, Guillermo. (2009). Lágrimas de Eros, Madrid: Museo Thyssen-Bornemisza.

V. V. A. A. (2010). Espejos del yo, Imágenes arquetípicas que dan forma a nuestras vidas, Barcelona: Kairós.

WARR, Tracey. y Jones, Amelia. (2006). El cuerpo del artista, Londres: Phaidon. Willis, Roy. (1993). Mitología. Guía ilustrada de los mitos del mundo. Madrid: Debate. ZuFFI, Stefano. (2001). Arte y erotismo. La fascinante relación entre arte y Eros, Milán: Electra.

Recibido el 31 de enero de 2020 Aceptado el 4 de noviembre de 2020 BIBLID [1132-8231 (2020): 11-26] 